\title{
Oral administration of Aloe vera gel, anti-microbial and anti-inflammatory herbal remedy, stimulates cell-mediated immunity and antibody production in a mouse model
}

\author{
BARBARA JOANNA BAEAN ${ }^{1}$, MARCIN NIEMCEWICZ ${ }^{2}$, JANUSZ KOCIK' ${ }^{2}$ LESZEK JUNG ${ }^{3}$, \\ EWA SKOPIŃSKA-RÓŻEWSKA ${ }^{4,2}$, PIOTR SKOPIŃSKI \\ ${ }^{1}$ Department of Immunology, Biochemistry and Nutrition, Warsaw Medical University, Warsaw, Poland \\ ${ }^{2}$ Military Institute of Hygiene and Epidemiology, Warsaw, Poland \\ ${ }^{3}$ CKR Rehabilitation Center, Konstancin-Jeziorna, Poland \\ ${ }^{4}$ Pathology Department, Center for Biostructure Research, Warsaw Medical University, Warsaw, Poland \\ ${ }^{5}$ Department of Histology and Embryology, Center for Biostructure Research, Warsaw Medical University, Warsaw, Poland
}

\begin{abstract}
Introduction: Aloe vera (L.) Burm. $f$. (Aloe barbadensis Mill) Liliaceae, succulent plant native to northern Africa, is presently cultivated in many regions of the world. Traditionally, its inner part of parenchyma, which contains aloe gel, was used for the treatment of minor wounds, inflammatory skin disorders, thermal and radiation burns and to alleviate chronic osteoarthritis pain. It also possesses some antimicrobial activity. Now, aloe gel is also increasingly consumed as a dietary supplement. Some data suggest its immunomodulatory properties.

The aim of the study was to evaluate the influence of orally administered aloe gel on some parameters of cellular and humoral immunity viz. mitogen-induced proliferation of splenic lymphocytes and their chemokinetic activity, and anti-sheep red blood cells (SRBC) antibody production in Balb/c mice.

Results: Daily treatment of mice for 14 and 21 days with $50 \mu \mathrm{l}$ or $150 \mu \mathrm{l}$ of aloe gel dose resulted in enhanced chemokinetic activity and stronger response of their splenic lymphocytes to mitogen PHA and enhancement of anti-SRBC antibody production.
\end{abstract}

Key words: aloe gel, antibody production, chemokinesis, mice, proliferation, splenocytes.

(Centr Eur J Immunol 2014; 39 (2): 125-130)

\section{Introduction}

Immunomodulation is an important factor for overcoming various acute and chronic infections, especially in the present times when various bacterial species have increasingly become resistant to antibiotics. Taking this into consideration, it has been proved that herbs showing both immunostimulatory and antimicrobial properties might provide useful alternative infections treatment. Aloe vera (Aloe barbadensis, Liliaceae) is a perennial succulent plant in tropical climates. Aloe gel, the colorless substance obtained from the parenchymatous cells in the fresh leaves of Aloe vera, contains polysaccharides (pectins, hemicelluloses, glucomannan, acemannan, and other mannose derivatives) and it should not be confused with the laxative drug "Aloe" (bitter yellow exudate containing anthracene glycosides, product of specialized resin canal cells in the thick leaf epidermis). These two products, despite the fact that they share certain components, have distinctly different properties. Traditionally, aloe gel was mainly used for treatment of inflammatory skin disorders, thermal and radiation burns, arthritis and for wound healing [1].

Recently, it has been reported that Aloe vera possess, both in vitro and in vivo, antimicrobial properties. Its in vitro inhibitory activity on some clinically isolated cariogenic and periodontopathic bacteria was described [2]. In other study, the bacteriostatic effect on Listeria monocytogenes, a bacteria responsible for foodborne diseases was observed [3]. Aloe gel and its extracts also exert antimicrobial activity against multidrug-resistant bacteria (MDR) from clinical isolates $[4,5]$. In the study of Kwon et al. [6], the antimicrobial activity of Aloe vera peel extract in distilled water against Staphylococcus aureus, Bacillus spp., Enterococcus spp., Escherichia coli, Salmonella typhimurium, Pseudomonas aeruginosa and Vibrio spp.

Correspondence: Ewa Skopińska-Różewska, Military Institute of Hygiene and Epidemiology, Kozielska 4, 01-163 Warsaw, Poland, tel. 600479 495, 601367 193, e-mail: ewaskop@hotmail.com 
was ascertained. The number of bacterial colonies was significantly reduced and the observed effect was especially strong against $E$. coli and Vibrio spp. $(p<0.01)$. Authors observed also in vivo antimicrobial activity of this extract against Salmonella typhimurium in mice. Gupta et al. [7] reported growth inhibition activity of aloe gel against MDR Mycobacterium tuberculosis isolates. On the other hand, it was observed [8] that Aloe vera juice incorporated into the growth media of Lactobacilli at a concentration of $5 \%$ was effective in promoting the growth of L. acidophilus, L. plantarum and L. casei. Whereas, concentration higher than $25 \%$ showed an inhibitory effect. Authors concluded that aloe gel in a lower concentration might be used in combination with probiotic Lactobacillus strains as a therapy for gastrointestinal disorders. Banu et al. observed aloe gel-mediated suppression of growth of MDR bacteria in human infected leg ulcers in 28 of 30 patients, by day 11 , after daily topical treatment. Cultures of the control group, treated with topical antibiotics, did not show any decrease in the bacterial growth by day 11 [9].

Aloe gel possesses anti-inflammatory properties. It was demonstrated in vitro that aloe gel suppressed bacterial-induced pro-inflammatory [tumor necrosis factor $\alpha$ (TNF- $\alpha$ ) and interleukin $1 \beta$ (IL-1 $\beta$ )] cytokines production in human immune cells [10]. In vivo, a protective effect of Aloe vera on polymicrobial sepsis in mice was reported [11]. In this study, administration of Aloe vera reversed the lethality and ameliorated the multiple organ dysfunction syndrome both by enhancing bacterial clearance and by attenuation of pro-inflammatory cytokines production. In vitro, an anti-inflammatory effect of Aloe vera was connected with down-regulation of MMP-9 activity [12].

The key symptom of rheumatoid arthritis is painful inflammation of the joints. There have been some scientific studies about Aloe vera and its use for easing arthritis pain. Oral Aloe vera could be used in the treatment of chronic non-cancer pain, particularly that caused by osteoarthritis [13]. Aloe vera administration topically also inhibits inflammation [14]. The gel of the Aloe vera plant can be also applied directly on the swollen and painful joints. The gel will provide relief of joint immobility and pain, due to its anti-inflammatory properties. Recently, it has been demonstrated that aloe gel acts as an effective gel base to prepare nimesulide emulgel with a significant anti-inflammatory effect for topical delivery in rheumatoid arthritis and other inflammatory conditions [15].

In ophthalmology, Aloe vera extracts may be used in eye drops to treat inflammations and other cornea ailments [16]. Data about the effect of aloe gel and its compounds on immunity are scanty, and mostly connected with its stimulatory effect on macrophages activity [17-19]. Primary screening of the immunotropic activity of aloe preparations elaborated by V.P. Filatov (tissue therapy) was done by Degtiarenko et al. [20]. They found that the studied bioregulators possess immunomodulating action on primary humoral immune response and do not increase a delayed type hypersensitivity reaction. Nersesian and Bogatyrieva showed, in 143 new cases of pulmonary tuberculosis that a combination of chemotherapy and aloe preparations had an immunomodulating effect [21].

The aim of the present study was to evaluate the in vivo influence of orally administered Aloe vera drinking gel on some parameters of cellular and humoral immunity: mitogen-induced proliferation and chemokinetic activity of splenic lymphocytes, and antibody production in Balb/c mice.

\section{Material and methods \\ Drug}

Tru-Alo 99\% Aloe vera Drinking Gel (Aloe barbadensis Miller folium succus), Aloin content $<40$ ppm; produced by HI TECH ALOE VERA PTY LTD, Bundaberg, Australia.

\section{Animals}

The study was performed on 91 female inbred Balb/c mice 6-8 weeks old, weighing about $20 \mathrm{~g}$, delivered from the Polish Academy of Sciences breeding colony. For all performed experiments animals were handled according to the Polish regulations concerning the wellness of laboratory animals (Polish National Institute of Health) standards. All experiments were accepted and conducted according to ethical guidance of the Local Bioethical Committee. Mice were housed 4-5 per cage and maintained under conventional conditions (room temperature $22.5-23.0^{\circ} \mathrm{C}$, relative humidity $50-70 \%, 12 \mathrm{~h}$ day/night cycle) with free access to standard rodent diet and water.

\section{Cell culture experiments}

$\mathrm{Balb} / \mathrm{c}$ mice were fed for 14 or 21 days with aloe gel ( $50 \mu \mathrm{l}$ or $150 \mu \mathrm{l}$ daily dose) in drinking water, or water (controls), then bled in anaesthesia (ketamine $100 \mathrm{mg} /$ kg-Ketamina $10 \%$, Biowet Pulawy, Poland and xylazine $10 \mathrm{mg} / \mathrm{kg}$, Sedazin, Biowet, Pulawy, Poland) and sacrificed by cervical dislocation. Aloe gel doses corresponded to $25 \mathrm{ml}$ or $75 \mathrm{ml}$ given to a person weighing $70 \mathrm{~kg}$ (applying the counter 7 for differences between mouse and human in relation of the surface to body mass). Splenocytes were isolated from their spleens under the sterile conditions by straining through stainless sieve and cotton gauze and centrifugation on Histopaque 1077 (Sigma-Aldrich, USA) for $8 \mathrm{~min}$ at $400 \mathrm{~g}$ in order to remove erythrocytes. Isolated splenocytes were resuspended in Parker culture medium (TC 199, BIOMED, Lublin, Poland).

Mitogen-induced (PHA) splenocytes proliferation assay was performed as previously described with some modifications [22, 23]. Briefly, before establishing the cultures, splenocytes from 2-3 Balb/c mice were pooled. Spleen cell cultures (in multiple repetitions) were incu- 
bated in Costar 96 well microplates $\left(10^{5}\right.$ cells in $0.2 \mathrm{ml}$ RPMI-1640 medium, Biomed Lublin, with $2 \mathrm{mM}$ L-glutamine, $10 \%$ FCS and antibiotics) with mitogen PHA (Murex, G.B.) at a concentration of $0.5,1$ and $2 \mu \mathrm{g} / \mathrm{ml}$, in a humidified atmosphere, at $37^{\circ} \mathrm{C}$, with $5 \% \mathrm{CO}_{2}$. After 48 $\mathrm{h}$ of incubation, $10 \mu \mathrm{l}$ of tritiated thymidine ( $3 \mathrm{HTdR}, 0.2$ $\mathrm{mCi} / \mathrm{ml}$, specific act. $2 \mathrm{Ci} / \mathrm{mM}$ ) was added. After further $24 \mathrm{~h}$, cells were harvested (Skatron) and incorporation of tritiated thymidine, measured using $\beta$-scintillation counter (Rack Beta 1218, LKB Wallac). The arithmetic mean of quadruplicate count was calculated and expressed as counts per minute (CPM).

\section{Spleen cells chemokinesis (spontaneous migration) assay}

Chemokinesis assay was performed in vitro according to the Sandberg method [24] in own modification [25]. Briefly, splenocytes were resuspended in Parker culture medium with 5\% inactivated FCS, at the final concentration of $30 \times 10^{6}$ cells $/ \mathrm{ml}$. Afterwards, siliconized capillary tubes were filled with cell suspension, sealed with plasticine, centrifuged ( $5 \mathrm{~min}, 450 \mathrm{~g}$ ) and fixed on the glass plates. Cell levels were marked. After $24 \mathrm{~h}$ incubation $\left(37^{\circ} \mathrm{C}, 5 \% \mathrm{CO}_{2}\right.$ humidified atmosphere) the distances of migration were measured in millimeters $(\mathrm{mm})$ at a magnification of $6.5 \times$ and presented as migration units $(1 \mathrm{MU}=0.18 \mathrm{~mm})$.

Study of antibody production was performed as previously described with some modification [26]. Briefly, Balb/c mice were fed for 14 days with aloe gel $50 \mu \mathrm{l}$ or $150 \mu \mathrm{l}$ daily dose in drinking water, or water (controls), then immunized with $10 \%$ SRBC ( $0.2 \mathrm{ml}$ intraperitoneally) and 7 days later bled in anaesthesia (ketamine $100 \mathrm{mg} / \mathrm{kg}$-Ketamina $10 \%$, Biowet, Pulawy, Poland and xylazine $10 \mathrm{mg} / \mathrm{kg}$ - Sedazin, Biowet, Pulawy, Poland) from retro-orbital plexus.

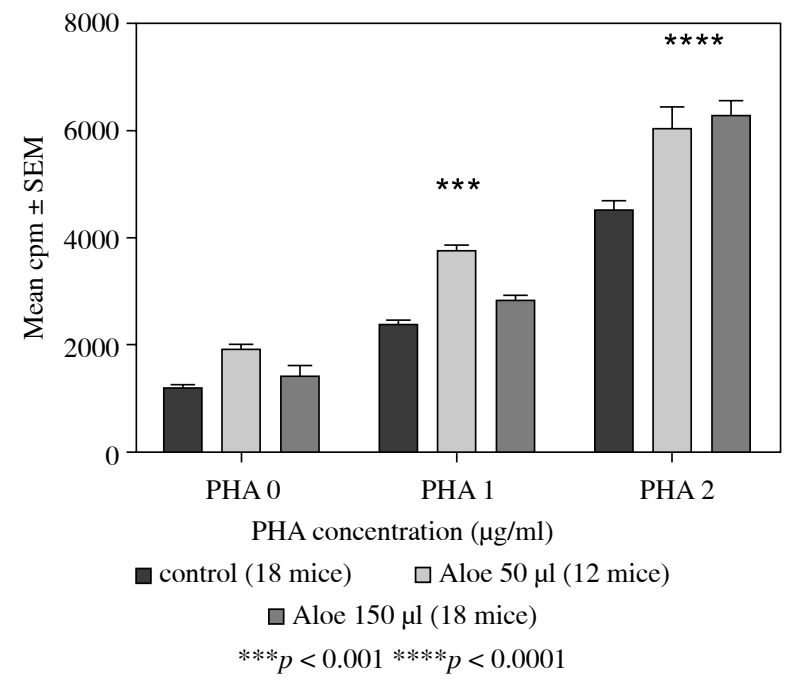

Fig. 1. The effect of aloe gel mice feeding for 21 days in $50 \mu \mathrm{l}$ or $150 \mu \mathrm{l}$ daily dose on the proliferation of their splenocytes in in vitro culture with mitogen PHA
The antibody level was evaluated with hemagglutination assay in inactivated $\left(56^{\circ} \mathrm{C}, 30 \mathrm{~min}\right)$ sera. A number of serum dilutions was performed (from $1: 1$ to $1: 1024$ ), applying PBS or $0.1 \mathrm{M}$ of 2-mercaptoethanol in PBS. After $60 \mathrm{~min}$ incubation at room temperature, $0.5 \%$ SRBC were added and the mixtures were incubated for another $60 \mathrm{~min}$ at room temperature, then centrifuged (10 min, $150 \mathrm{~g})$ and shaken. The hemagglutination titer was evaluated in a light microscope - as the last dilution, in which at least 3 cell conglomerates were present in at least 3 consecutive fields at objective magnification $20 \times$.

\section{Statistical analysis}

Statistical evaluation of the results was performed by two-way ANOVA and Bonferroni Multiple Comparison PostTest (GraphPadPrism).

\section{Results}

The results of splenocytes proliferation in cell cultures established with mitogen PHA are presented in Fig. 1. Cells collected from aloe-fed animals responded more vigorously to mitogen than cells isolated from the spleens of control mice. Feeding mice with a lower dose of aloe gel resulted in better splenocytes response to a lower dose of mitogen than feeding with a higher one. Response to a higher dose of PHA was the same in both aloe-fed groups.

The results of experiments performed for evaluation of the influence of in vivo aloe gel administration to mice on the in vitro spontaneous migration of their splenocytes in tissue culture, are presented in Fig. 2. In this type of experiment, a stimulatory effect was observed only in mice fed with a higher $(150 \mu \mathrm{l})$ daily dose of aloe gel, disregarding whether they belong to the group fed for 14 or 21 days.

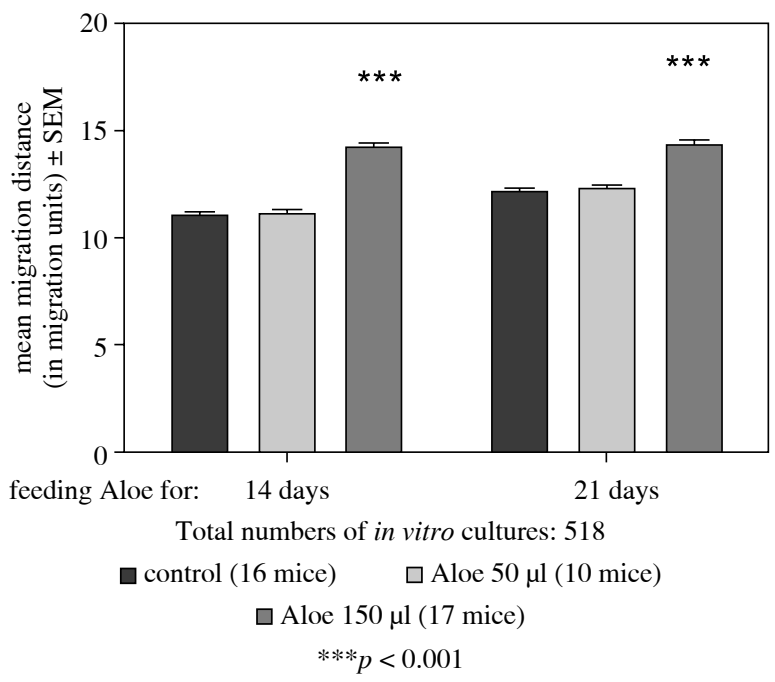

Fig. 2. The effect of aloe gel mice feeding for 14 or 21 days on the ex vivo chemokinetic (spontaneous migratory) activity of their splenic cells in $24 \mathrm{~h}$ tissue culture 


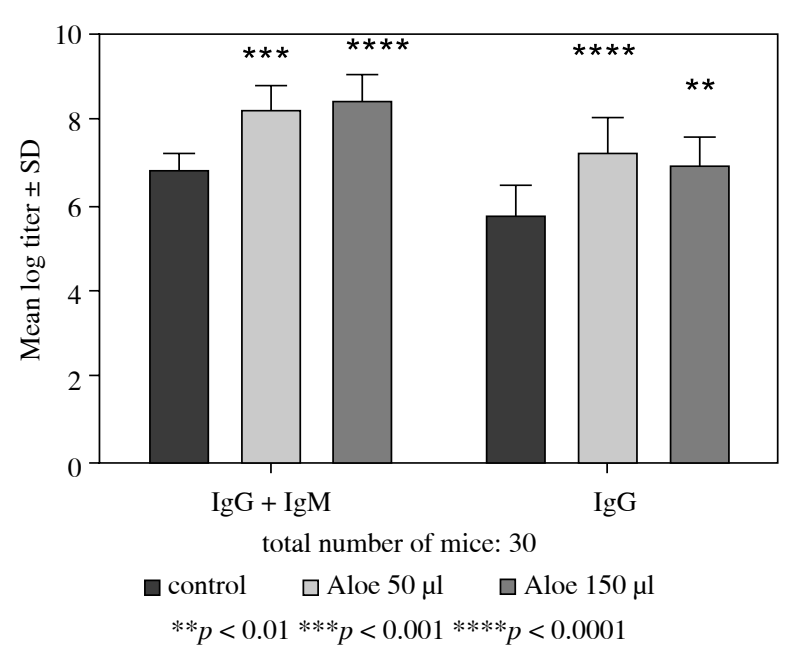

Fig. 3. Stimulatory effect of aloe gel feeding on anti-SRBC antibody production in mice

Feeding mice with Aloe vera gel for 14 days enhanced 2-mercaptoethanol + resistant, anti-SRBC $7 \mathrm{~S}$ (IgG) antibody production, disregarding the aloe daily dose (Fig. 3).

\section{Discussion}

The aloe leaf can be processed into two types of juices for commercial use: inner gel juice, produced from gelatinous parenchyma of the leaf, and decolorized whole leaf juice, produced by treatment of ground leaf with activated charcoal, to remove aloe latex. Toxicological studies of aloe gel and its main polysaccharide (acemannan) did not reveal adverse effects associated with a high intake of these products at acute or subchronic periods [27-29].

In the present paper we have found for the first time that aloe gel feeding of experimental mice increased their splenic cells mobility and response to mitogen PHA, as well as anti-SRBC antibody production. Vahedi et al. described in rabbits, fed with Aloe vera extract, an increase in CD4 lymphocyte frequency in blood and serum immunoglobulin concentrations [30]. The Aloe vera was suggested to be involved in the differentiation of CD4 lymphocytes, by means of regulating the expression of $\mathrm{TH} 1$ and $\mathrm{TH} 2$ cytokines [31].

Recently, Halder et al. has reported, in rats fed with the aqueous extract of Aloe vera, augmented anti-SRBC antibody production and decreased delayed-type hypersensitivity to keyhole limpet hemocyanin [32]. Enhancement of anti-SRBC antibody production and health improvement were also observed in chickens suffering from coccidiosis, administered with the Aloe vera extract [33]. Similarly, the protective effect of Aloe vera-based diet in Eimeria maxi$m a$-infected broiler chickens was observed [34].

In vitro, Topman et al. did not observe the effect of Aloe vera on other cell (fibroblast) motility [35], in vivo, in agreement with our results obtained ex vivo with splenic lymphocytes, but in a different experimental model, Liu $e t$ al. reported stimulation of macrophage migration by polysaccharides derived from aloe gel [18]. In humans, the in vitro and in vivo impact of Aloe vera juice plus vitamin $\mathrm{C}$ on natural killer (NK) cells activity, was assessed in 27 healthy volunteers. Cytotoxicity of NK cells was significantly increased compared to the pre-supplementation values [36].

Aloe gel is a rich source of polysaccharides, of which mannose-6-phosphate and acemannan are major constituents responsible for its immunomodulatory activity and other, which e.g. enhance the antitumor activity of chemotherapy drugs [37-39]. It was reported that acemannan, a major carbohydrate fraction of aloe gel, promoted differentiation of immature dendritic cells generated from mouse bone marrow, what might partly explain its immunostimulatory activity [40].

Oligosaccharides prepared from purified aloe polysaccharide prevented suppression of DTH responses in vivo and reduced the amount of IL-10 observed in ultraviolet irradiated murine epidermis [41]. High-mannose biological response modifiers, purified from Aloe veralbarbadensis leaf parenchyma gel, expressed adjuvant immune activity [42], enhancing anti-coxsackievirus antibody titers in mice [43], improving both the quality of life and the survival rate of oncornavirus-infected cats [44,] and, in a murine model, stimulating peritoneal macrophages and splenic $\mathrm{T}$ and $\mathrm{B}$ cells to secrete TNF- $\alpha$, IL- $1 \beta$, INF- $\gamma$, IL- 2 and IL-6 [45]. Im et al. have found that polysaccharides between 400 and 5KDa of molecular size exhibited the most potent macrophage-activating activity in vitro and most potent antitumor activity in vivo [46].

\section{Conclusions}

These data demonstrate that aloe gel administered orally to mice behaves as a stimulator of cellular and humoral immunity, increasing their splenic cells mobility and response to mitogen PHA, and anti-SRBC antibody production.

The authors declare no conflict of interest.

\section{References}

1. WHO Monographs on Selected Medicinal Plants. Volume 1: Aloe vera gel. http://apps.who.int/medicinedocs/en/d/ Js2200e/6.html.

2. Fani M, Kohanteb J (2012): Inhibitory activity of Aloe vera gel on some clinically isolated cariogenic and periodontopathic bacteria. J Oral Sci 54: 15-21.

3. Ramirez Merida LG, Moron de Salim A, Catinella R, Castillo L (2012): Bacteriostatic and/or bactericidal extract of Aloe vera 
gel on cultures of Listeria monocytogenes. Arch Latinoam Nutr 62: 73-78.

4. Shilpakala SR, Prathiba J, Malathi R (2009): Susceptibilities of Escherichia coli and Staphylococcus aureus to Aloe barbadensis. Eur Rev Med Pharmacol Sci 13: 461-464.

5. Dahiya P, Purkayastha S (2012): Phytochemical screening and antimicrobial activity of some medicinal plants against multi-drug resistant bacteria from clinical isolates. Indian J Pharm Sci 74: 443-450.

6. Kwon KH, Hong MK, Hwang SY, et al. (2001): Antimicrobial and immunomodulatory effects of Aloe vera peel extract. J Medic Plant Res 5: 5384-5392.

7. Gupta R, Thakur B, Singh P, et al. (2010): Anti-tuberculosis activity of selected medicinal plants against multi-drug resistant Mycobacterium tuberculosis isolates. Indian J Med Res 131: 809-813.

8. Nagpal R, Kaur V, Kumar M, Marotta F (2012): Effect of Aloe vera juice on growth and activities of Lactobacilli in vitro. Acta Biomed 83: 183-188.

9. Banu A, Sathyanarayana B, Chattannavar G (2012): Efficacy of fresh Aloe vera gel against multi-drug resistant bacteria in infected leg ulcers. Australas Med J 5: 305-309.

10. Habeeb F, Stables G, Bradbury F, et al. (2007): The inner gel component of Aloe vera suppresses bacterial-induced pro-inflammatory cytokines from human immune cells. Methods 42: 388-393.

11. Yun N, Lee CH, Lee SM (2009): Protective effect of Aloe vera on polymicrobial sepsis in mice. Food Chem Toxicol 47: 1341-1348.

12. Vijayalakshmi D, Dhandapani R, Jayaveni S, et al. (2012): In vitro anti inflammatory activity of Aloe vera by down regulation of MMP-9 in peripheral blood mononuclear cells. J Ethnopharmacol 141: 542-546.

13. Cowan D (2010): Oral Aloe vera as a treatment for osteoarthritis. Brit J Commun Nurs 15: 280-282.

14. Davis RH, Rosenthal KY, Cesario LR, Rouw GA (1989): Processed Aloe vera administered topically inhibits inflammation. J Am Podiatr Med Assoc 79: 395-397.

15. Vandana KR, Yalavarthi PR, Sundaresan CR, et al. (2014): In vitro assessment and pharmacodynamics of Nimesulide incorporated Aloe vera Transemulgel. Curr Drug Discov Technol 11: 162-167.

16. Woźniak A, Paduch R (2012): Aloe vera extract activity on human corneal cells. Pharm Biol 50: 147-154.

17. Stuart RW, Lefkowitz DL, Lincoln JA, et al. (1997): Upregulation of phagocytosis and candidicidal activity of macrophages exposed to the immunostimulant acemannan. Int J Immunopharmacol 19: 75-82.

18. Liu C, Leung MY, Koon JC, et al. (2006): Macrophage activation by polysaccharide biological response modifier isolated from Aloe vera L. var. chinensis (Haw.) Berg. Int Immunopharmacol 6: 1634-1641.

19. Farahnejad Z, Ghazanfari T, Yaraee R (2011): Immunomodulatory effects of Aloe vera and its fractions on response of macrophages against Candida albicans. Immunopharmacol Immunotoxicol 33: 676-681.

20. Degtiarenko TV, Ivanova AS, Skvortsov VIu, et al. (1989): Primary screening of the immunopharmacologic activity of Filatov tissue therapy preparations. Oftalmol Zh 1: 34-39.

21. Nersesian ON, Bogatyreva EV (1980): Effect of chemotherapy combined with the use of tissue preparations on nonspecific immunity in patients with pulmonary tuberculosis. Probl Tuberk 1: 28-31.
22. Skopińska-Różewska E, Furmanowa M, Guzewska J, et al. (2002): The effect of Centella asiatica, Echinacea purpurea and Melaleuca alternifolia on cellular immunity in mice. Centr Eur J Immunol 27: 142-148.

23. Skopińska-Rózewska E, Sokolnicka I, Siwicki AK, et al. (2011): Dose-dependent in vivo effect of Rhodiola and Echinacea on the mitogen-induced lymphocyte proliferation in mice. Pol J Vet Sci 14: 265-272.

24. Sandberg G (1976): The sealed capillary migration technique and thymocyte migration in vitro. J Immunol Methods 12: 365-368.

25. Skopińska-Różewska E, Bychawska M, Białas-Chromiec B, Sommer E (2009): The in vivo effect of Rhodiola rosea and Rhodiola quadrifida hydro-alcoholic extracts on chemokinetic activity of spleen lymphocytes in mice. Centr Eur J Immunol 34: $42-45$.

26. Skopińska-Różewska E, Stankiewicz W, Zdanowski R, et al. (2012): The in vivo effect of Rhodiola quadrifida extracts on the antibody production, on the blood leukocytes subpopulations and on the bacterial infection in mice. Centr Eur J Immunol 37: 140-144.

27. Sehgal I, Winters WD, Scott M, Kousoulas K (2013): An in vitro and in vivo toxicologic evaluation of a stabilized aloe vera gel supplement drink in mice. Food Chem Toxicol 55: 363-370.

28. Sehgal I, Winters WD, Scott M, et al. (2013): Toxicologic assessment of a commercial decolorized whole leaf Aloe vera juice, Lily of the desert filtered whole leaf juice with aloesorb. J Toxicol 2013; 2013: 802453.

29. Fogleman RW, Chapdelaine JM, Carpenter RH, McAnalley BH (1992): Toxicologic evaluation of injectable acemannan in the mouse, rat and dog. Vet Hum Toxicol 34: 201-205.

30. Vahedi G, Taghavi M, Maleki AK, Habibian R (2011): The effect of Aloe vera extract on humoral and cellular immune response in rabbit. Afr J Biotechnol 10: 5225-5228.

31. Yu H, Dong Z, Yang Z (2002): Molecular biological study of Aloe vera in the treatment of experimental allergic rhinitis in rat. Lin Chuang Er Bi Yan Kou He Za Zhi 16: 229-231.

32. Halder S, Mehta AK, Mediratta PK (2012): Augmented humoral immune response and decreased cell-mediated immunity by Aloe vera in rats. Inflammopharmacology 20: 343-346.

33. Akhtar M, Hai A, Awais MM, et al. (2012): Immunostimulatory and protective effects of Aloe vera against coccidiosis in industrial broiler chickens. Vet Parasitol 186: 170-177.

34. Yim D, Kang SS, Kim DW, et al. (2011): Protective effects of Aloe-vera based diets in Eimeria maxima-infected broiler chickens. Exp Parasitol 127: 322-325.

35. Topman G, Lin FH, Gefen A (2013): The natural medications for wound healing-Curcumin, Aloe vera and Ginger - do not induce a significant effect on the migration kinematics of cultured fibroblasts. J Biomech 46: 170-174.

36. Toliopoulos I, Simos Y, Verginadis I, et al. (2012): NK cell stimulation by administration of vitamin $\mathrm{C}$ and Aloe vera juice in vitro and in vivo: a pilot study. J Herbal Med 2: 29-33.

37. Wang Z, Wang Y, Huang Z, et al. (2001): Study on antitumor effect and mechanism of aloe polysaccharides. Zhong Yao Cai 24: 350-353.

38. Choi S, Chung MH (2003): A review on the relationship between Aloe vera components and their biologic effects. Semin Integr Med 1: 53-62.

39. Talmadge J, Chavez J, Jacobs L, et al. (2004): Fractionation of Aloe vera $\mathrm{L}$. inner gel, purification and molecular profiling of activity. Int Immunopharmacol 4: 1757-1773. 
40. Lee JK, Lee MK, Yun YP, et al. (2001): Acemannan purified from Aloe vera induces phenotypic and functional maturation of immature dendritic cells. Int Immunopharmacol 1: 12751284.

41. Byeon SW, Pelley RP, Ullrich SE, et al. (1998): Aloe barbadensis extracts reduce the production of interleukin-10 after exposure to ultraviolet radiation. J Invest Dermatol 110: 811-817.

42. t'Hart LA, van den Berg AJ, Kuis L, et al. (1989): An anti-complementary polysaccharide with immunological adjuvant activity from the leaf parenchyma gel of Aloe vera. Planta Med 55: 509-512.

43. Gauntt CJ, Wood HJ, McDaniel HR, McAnalley BH (2000): Aloe polymannose enhances anti-coxsackievirus antibody titres in mice. Phytother Res 14: 261-266.

44. Sheets MA, Unger BA, Giggleman GF Jr, Tizard IR (1991): Studies of the effect of acemannan on retrovirus infections: clinical stabilization of feline leukemia virus-infected cats. Mol Biother 3: 41-45.

45. Leung MY, Liu C, Zhu LF, et al. (2004): Chemical and biological characterization of a polysaccharide biological response modifier from Aloe vera $\mathrm{L}$. var. Chinensis (Haw.) Berg. Glycobiology 14: 501-510.

46. Im SA, Oh ST, Kim MR, et al. (2005): Identification of optimal molecular size of modified Aloe polysaccharides with maximum immunomodulatory activity. Int Immunopharmacol 5: 271-279. 